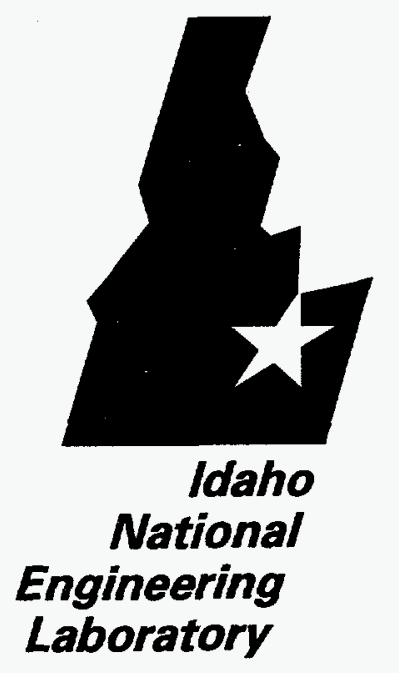

INEL-96/0060

February 1996

Tribal and Public Involvement in the U.S. Department of Energy Mixed Waste Focus Area -

First Quarter Status Report for the Period Ending December 31, 1995

Katherine J. Owens

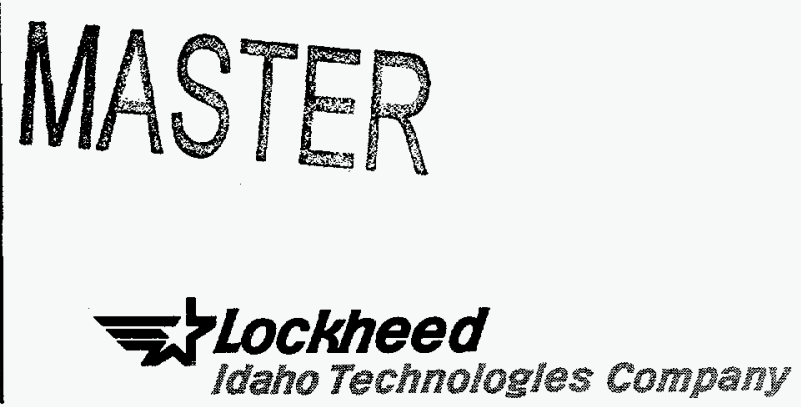


3 


\title{
Tribal and Public Involvement in the U.S. Department of Energy Mixed Waste Focus Area - First Quarter Status Report for the Period Ending December 31, 1995
}

\author{
Katherine J. Owens
}

Published February 1996

\author{
Idaho National Engineering Laboratory \\ Mixed Waste Focus Area \\ Lockheed Idaho Technologies Company \\ Idaho Falls, Idaho $\mathbf{8 3 4 1 5}$
}

Work Performed by the

U.S. Department of Energy

Under DOE Idaho Operations Office

Contract DE-AC07-941D13223 



\section{DISCLAIMER}

Portions of this document may be illegible in electronic image products. Images are produced from the best available original document. 


\title{
ABSTRACT
}

The U.S. Department of Energy (DOE) Mixed Waste Focus Area (MWFA) began operations in February 1995 to provide technologies for the design, construction, and operation of implementable mixed waste treatment systems as identified in DOE Site Treatment Plans of the Federal Facilities Compliance Act. Implementable mixed waste treatment systems means that they meet the MWFA success criteria and that potential barriers to implementing those treatment systems have been identified and eliminated through effective communications and meaningful involvement with regulators, stakeholders, and tribal governments. The Regulatory and External Liaison Product Area of the MWFA is responsible for ensuring that possible teaming arrangements are considered and integrated into the MWFA technology development and decision-making processes. The Tribal and Public Involvement Team of the MWFA Regulatory and External Liaison Product Area has initiated a variety of activities to facilitate tribal and stakeholder involvement within the MWFA. This document discusses the status of those activities as of the end of the first quarter of the 1996 fiscal year and describes applicable lessons learned and process improvements.

\section{DISCLAIMER}

\begin{abstract}
This report was prepared as an account of work sponsored by an agency of the United States Government. Neither the United States Government nor any agency thereof, nor any of their employees, makes any warranty, express or implied, or assumes any legal liability or responsibility for the accuracy, completeness, or usefulness of any information, apparatus, product, or process disclosed, or represents that its use would not infringe privately owned rights. Reference herein to any specific commercial product, process, or service by trade name, trademark, manufacturer, or otherwise does not necessarily constitute or imply its endorsement, recommendation, or favoring by the United States Government or any agency thereof. The views and opinions of authors expressed herein do not necessarily state or reflect those of the United States Government or any agency thereof.
\end{abstract}




\section{CONTENTS}

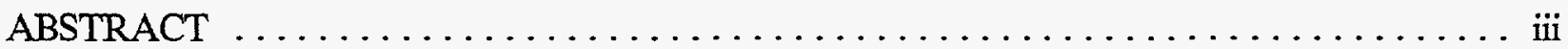

ACRONYMS $\ldots \ldots \ldots \ldots \ldots \ldots \ldots \ldots \ldots \ldots \ldots \ldots \ldots \ldots \ldots \ldots \ldots \ldots \ldots \ldots \ldots$

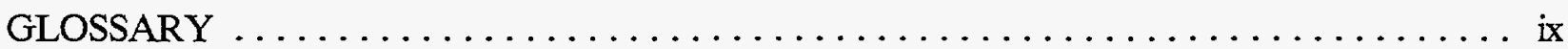

1. INTRODUCTION $\ldots \ldots \ldots \ldots \ldots \ldots \ldots \ldots \ldots \ldots \ldots \ldots \ldots \ldots \ldots \ldots$

1.1 Ownership and Origin $\ldots \ldots \ldots \ldots \ldots \ldots \ldots \ldots \ldots \ldots \ldots \ldots \ldots \ldots \ldots \ldots \ldots \ldots \ldots$

1.2 Purpose $\ldots \ldots \ldots \ldots \ldots \ldots \ldots \ldots \ldots \ldots \ldots \ldots \ldots \ldots \ldots \ldots \ldots \ldots \ldots$

1.3 Background $\ldots \ldots \ldots \ldots \ldots \ldots \ldots \ldots \ldots \ldots \ldots \ldots \ldots \ldots \ldots \ldots \ldots$

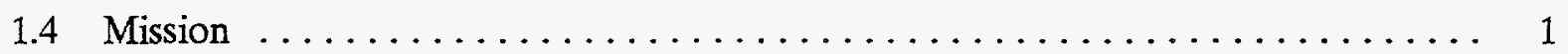

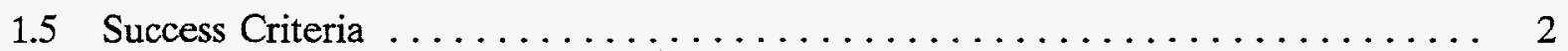

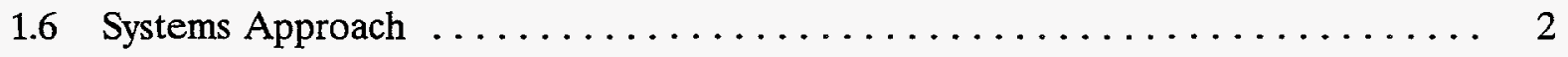

1.7 MWFA Regulatory and External Liaison Product Area $\ldots \ldots \ldots \ldots \ldots \ldots \ldots$

2. TRIBAL AND PUBLIC INVOLVEMENT $\ldots \ldots \ldots \ldots \ldots \ldots \ldots \ldots \ldots \ldots$

2.1 Goals and Objectives $\ldots \ldots \ldots \ldots \ldots \ldots \ldots \ldots \ldots \ldots \ldots \ldots \ldots$

2.2 Tribal and Public Involvement Steering Committee $\ldots \ldots \ldots \ldots \ldots \ldots$

2.3 Communications $\ldots \ldots \ldots \ldots \ldots \ldots \ldots \ldots \ldots \ldots \ldots \ldots \ldots \ldots \ldots \ldots \ldots$

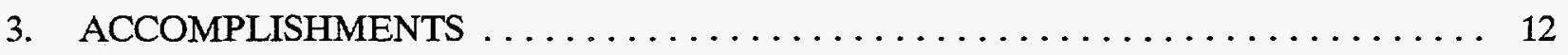

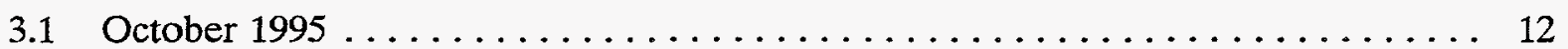

3.1.1 MWFA TPISC Meeting . . . . . . . . . . . . . . . 12

3.1.2 A Model for Tribal and Stakeholder Involvement in the MWFA System . . 12

3.1.3 Lessons Learned - Permitting R\&D Activities . . . . . . . . . . . . . . 12

3.1.4 OST Exhibition for the United States Senate $\ldots \ldots \ldots \ldots \ldots \ldots \ldots \ldots$

3.1.5 MWFA Advertisements ......................... 13

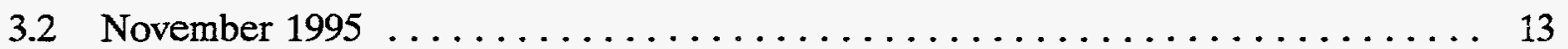

3.2.1 Plasma Hearth Process (PHP) Open House . . . . . . . . . . . . . 13

3.2.2 TRU, Mixed TRU, and MLLW Treatment Technologies Technical Peer

Review 
3.2.3 MWFA Marketing and Communication Implementation Schedule . . . . . 14

3.2.4 U.S. DOE MWFA Tribal and Public Involvement Plan . . . . . . . . . . 15

3.2 .5 Environmental Management Forum $\ldots \ldots \ldots \ldots \ldots \ldots \ldots \ldots \ldots \ldots$

3.2.6 Envirocare Facility Tour . . . . . . . . . . . . . . . . 16

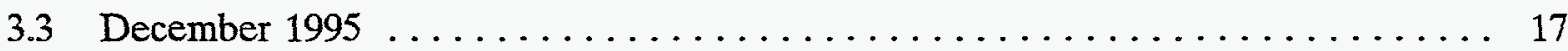

3.3.1 MWFA Crosswalk Between Stakeholder Principles and Technical Criteria . 17

3.3.2 MWFA Public Involvement and Communications Organization and External Interfaces . . . . . . . . . . . . . . . . . 18

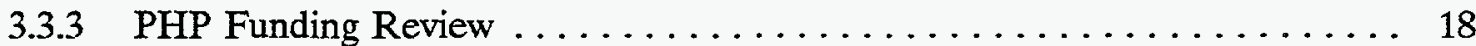

3.3 .4 MWFA/CLN Meeting . . . . . . . . . . . . . . . . 19

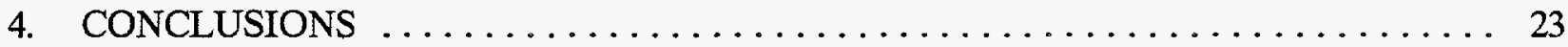

5. REFERENCES $\ldots \ldots \ldots \ldots \ldots \ldots \ldots \ldots \ldots \ldots \ldots \ldots \ldots \ldots \ldots \ldots \ldots$

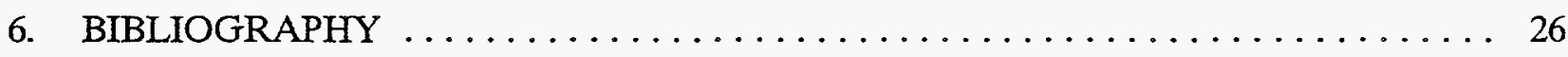

\section{FIGURES}

1. MWFA systems architecture $\ldots \ldots \ldots \ldots \ldots \ldots \ldots \ldots \ldots \ldots \ldots \ldots \ldots$

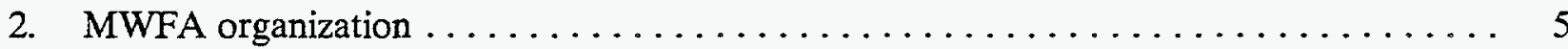

3. MWFA decision-making paradigm $\ldots \ldots \ldots \ldots \ldots \ldots \ldots \ldots \ldots \ldots \ldots \ldots \ldots \ldots \ldots \ldots \ldots$

4. Tribal and public involvement organization $\ldots \ldots \ldots \ldots \ldots \ldots \ldots \ldots \ldots$

5. Technical baseline development process - Phase II $\ldots \ldots \ldots \ldots \ldots \ldots \ldots \ldots$

\section{TABLES}

1. MWFA product requirements (success criteria) $\ldots \ldots \ldots \ldots \ldots \ldots \ldots \ldots \ldots$

2. MWFA communications internal and external audiences $\ldots \ldots \ldots \ldots \ldots \ldots \ldots$ 


\section{ACRONYMS}

ADS

CLN

DOE

DOE-HQ

DOE-ID

DOIT

EM

EM50

EPA

FFCA

INEL

INTS

ITRC

LITCO

MLLW

MWFA

NEPA

NTW

OST

PHP

$R \& D$

RCRA

RDS
Activity Data Sheets

Community Leaders Network

Department of Energy

Department of Energy Headquarters

Department of Energy Idaho Operations Office

Develop On-site Innovative Technologies

Environmental Management

Environmental Management Office of Science and Technology

Environmental Protection Agency

Federal Facility Compliance Act

Idaho National Engineering Laboratory

Integrated Non-thermal Treatment Studies

Interstate Technology and Regulatory Cooperation

Lockheed Idaho Technologies Company

mixed low-level radioactive waste

Mixed Waste Focus Area

National Environmental Policy Act of 1969

National Technical Workgroup

Office of Science and Technology (EM50)

plasma hearth process

research and development

Resource Conservation and Recovery Act

Risk Data Sheets 
SAIC

SSAB

STCG

TPISC

TTP

TRU

WTM

WTT
Science Applications International Corporation

Site Specific Advisory Board

Site Technology Coordination Group

Tribal and Public Involvement Steering Committee

Technical Task Plan

transuranic waste

waste type manager

waste type team 


\section{GLOSSARY}

analysis

bench scale

deficiency

deliver

demonstration

end-user
When used to mean a method of verification, analysis is process used in lieu of or in addition to testing to verify compliance with specifications. The techniques typically include interpretation or interpolation/extrapolation of analytical or empirical data under defined conditions or reasoning to show theoretical compliance with stated requirements.

The term "bench-scale" implies "bench-scale testing" using the definition of "bench-scale testing" from McGraw-Hill Dictionary of Scientific and Technical Terms - testing of materials, methods, or chemical processes on a small scale, such as a laboratory worktable (see exploratory development).

See technology deficiency.

Deliver means to take to the intended recipient, where the technology and/or treatment system is in the form of a readable (paper or electronic) record, and the intended recipient is the "end-user."

1. When used to mean a method of verification, demonstration is an exhibition of the operability or supportability of an item under intended service-use conditions. These verifications are usually non-repetitive and are oriented almost exclusively toward acquisition of qualitative data. Demonstrations may be accomplished by computer simulation.

2. When used as Stage 6 of the Paladino decision model, refers to the stage following engineering development. (Generally the word demonstration will be used with its ordinary English language definition.) The demonstration stage implies the testing of a production prototype. The production prototype will be full scale and occur a joint activity with the end-user, generally at the enduser's facility. Work performed during this stage (when successful) results in an operable prototype, a signed commitment by the enduser to use the technology, and public acceptance of the technology. Decision Gate 6 is at the end of Stage 6.

End-user means organizations responsible for storage, treatment (processing), and disposal of mixed wastes. To the extent that the waste generator is responsible for storage, treatment and disposal, the generator may also be an end-user. Most end-users belong to DOE organizations EM-30, EM-40, and EM-60. Potential end-users include companies or industrial organizations who propose to establish mixed waste TSD facilities. 
facility

hazardous materials

mixed waste

quick wins

stakeholder

systems engineering
Facility means one of the following: a treatment, storage, characterization, transportation, or disposal operation, or set of buildings, land, and organization dedicated to treatment, storage, characterization, transportation, or disposal of mixed waste whether or not it is operating. Such operation may be existing, on-site DOE, or off-site non-DOE operation. It may also include any similar proposed DOE facility that has progressed at least to the initiation of conceptual design. A facility may consist of one or more treatment systems.

Hazardous material means any solid, liquid, or gaseous material that is toxic, explosive, flammable, corrosive, or otherwise physically or biologically threatening to health. Oil is excluded from this definition.

Mixed waste are wastes that are both radioactive in accordance with DOE Order 5820.2A and hazardous in accordance with 40 Code of Federal Regulations Part 261. In the MWFA, the term mixed waste refers only to mixed low-level radioactive and mixed transuranic wastes. Mixed high-level wastes are specifically excluded from the scope of the program.

Quick wins are activities that lead to expedited demonstration and/or implementation of mixed waste treatment technologies. (Detailed requirements to class a project as a quick win may be found in internal letter OPE/MWFA-96-017.)

Stakeholder means all those who have an interest in the outcome of the program and includes: the public, tribal governments, regulatory agencies, universities, and industries. Members of the DOE and DOE contractors who have a direct and immediate interest or involvement in the MWFA are not considered stakeholders.

Systems engineering is a formalized process that translates customer needs and objectives, in concert with applicable external constraints, into system functions and requirements. These functions and requirements define the desired system and the final product, and, in turn, drive and control the system design. Systems engineering is an iterative process which tracks and manages change, progress, and costs. Changes and choices are tracked and documented; decisions are supported by objective analysis and trade studies. As the project evolves, tests are defined and executed to verify that the requirements have or will be met and that the final system will perform all required functions. The system is subdivided into subsystems small enough to manage and track. The technical design and analysis are integrated into the project management and cost control systems. 
technical contact

technology deficiency

technology investment decision model

test

treatment

treatment system

treatment train
Technical contact means an individual with an academic background that includes as a minimum a B. S. Degree in Engineering (such as chemical, mechanical, electrical, etc.), Environmental Science, Chemistry, Physics, or Geology, or equivalent experience. Also referred to as, Technical Resource Team.

A technology deficiency is a roadblock related to a technical aspect of characterization, treatment, handling, or disposal of mixed wastes which prevents the timely, safe, and/or cost effective characterization, treatment, handling, or disposal of those wastes. The term is generally referred to simply as "deficiency." (Specific deficiencies are identified and defined in the Mixed Waste Focus Area Integrated Technical Baseline Report, DOE/ID-10524.)

A model illustrating decision points in research and development stages as research progresses from basic research to implementation.

When used to mean a method of verification, test is an action by which the operability, supportability, performance capability or other specified qualities of an item are verified when subjected to controlled conditions that are real or simulated. These verifications may require use of special test equipment and instrumentation to obtain quantitative data for analysis as well as qualitative data derived from displays and indicators inherent in the item(s) for monitor and control.

Treatment means any action on a waste that results in a man-induced change-of-state in the waste. Treatment includes any action from the point of generation to disposal of the waste, and therefore includes: characterization, storage, processing, transportation, and disposal.

A treatment system is logical assemblage of unit operations organized to operate on a waste stream and product a waste form which meets disposal criteria. In the parlance of the technical baseline, a treatment system may consist of one or more treatment train as applied to a specific facility. Beyond the technical baseline, the distinction between treatment train and treatment system is blurred. A treatment system must have a target waste stream and a potential programmatic owner (see treatment train).

A treatment train is a process flow diagram for a specific waste stream. It contains more detail than a process flow diagram and will begin to identify specific unit operations for most of the process steps. A treatment train depicts a generic treatment (starting from an existing waste stream through disposal) and will generally have no direct association with a specific system (see treatment system). 
The term "waste type(s)" is used to refer to treatability groups (of wastes) based on definitions in the DOE Waste Treatability Guidance, DOE/LLW-217, generated as part of the Federal Facility Compliance Act process. The DOE/LLW-217 categories have been grouped into the following five waste types used by the MWFA: waste water, combustible organics, sludges, debris, and unique wastes. (Each of these five waste types are defined separately in this glossary.) 


\section{Tribal and Public Involvement in the U.S. Department of Energy Mixed Waste Focus Area}

\section{INTRODUCTION}

\subsection{Ownership and Origin}

This report was prepared for the Mixed Waste Focus Area (MWFA) Program in response to the requirements set forth in the MWFA Regulatory and External programs Technical Task Plan (TTP) Number ID06MW83. The MWFA Program is managed by the U.S. Department of Energy Idaho Operations Office (DOE-ID) and supported by the Lockheed Idaho Technologies Company (LITCO). The program funding is received under Activity Data Sheet (ADS) Number HQ-0000-MW-00. LITCO support is managed under DOE-ID Contract DE-AC07-94ID13223.

\subsection{Purpose}

The purpose of this report is to discuss the tribal and public involvement activities initiated or accomplished by the MWFA during the first quarter of the 1996 fiscal year (FY-96). Applicable lessons learned and process improvements are included where appropriate. Addendums to this report will be issued on a quarterly basis throughout the remainder of FY-96.

\subsection{Background}

The DOE established the MWFA to solve the problem of lack of accepted treatment technology and disposal capacity for mixed low-level radioactive waste (MLLW) and mixed transuranic waste (TRU), and the high cost of that which is available. The Idaho National Engineering Laboratory (INEL) was selected as the lead organization to provide technical management of the MWFA and to establish an implementation team to carry out the MWFA mission.

\subsection{Mission}

The mission of the MWFA is to provide acceptable treatment systems, capable of treating DOE's mixed waste, which have been developed in partnership with users and with continual participation of stakeholders, tribal governments, and regulators. The MWFA mission was borne of the Resource Conservation and Recovery Act (RCRA) as amended by the Federal Facility Compliance Act (FFCA). Under the FFCA, every DOE facility generating or storing mixed waste was required to develop a plan for treating those wastes. Those plans are called Site Treatment Plans and describe the mixed waste treatment capabilities or proposed mixed waste treatment systems of each site. Agreements were negotiated with each host state, resulting in enforceable consent orders for the implementation of those proposed treatment systems. 


\subsection{Success Criteria}

The MWFA management team recognizes that successful implementation of those proposed treatment systems rests with its ability to deliver technologies that meet the following success criteria: technically correct, technically complete, acceptable to stakeholders, ${ }^{a}$ acceptable to an end-user, permittable, safe, timely, cost-effective, and sufficient (see Table 1). Therefore, to minimize the impacts of limiting factors and maximize opportunities for success, technologies delivered by the MWFA will be developed in partnership with end-users and with continual input from stakeholders, tribal governments, and regulators.

\subsection{Systems Approach}

The MWFA has implemented a systems engineered approach that identifies top-level requirements and performance measurements to ensure that delivered technologies meet the success criteria (see Figure 1). The systems approach defines and integrates the performance requirements for the success criteria as they apply to the proposed site treatment systems for which the MWFA is delivering technologies.

\subsection{MWFA Regulatory and External Liaison Product Area}

The MWFA organizational structure is designed to maximize its ability to meet those success criteria through four primary product areas: (1) Systems Engineering, (2) Technology Coordination, (3) Regulatory and External Liaison, and (4) Program Integration and Control (see Figure 2). The Regulatory and External Liaison Product Area of the MWFA implementation team is responsible for facilitating regulatory, university, industry, public, and tribal input to the MWFA waste type teams (WTT). This input helps to define needs, address regulatory options, and provide early tribal and stakeholder involvement in product development, and is integral to the MWFA decision-making process for technology selection, prioritization, and evaluation (see Figure 3).

\footnotetext{
a. For the purpose of this paper, the term "stakeholders" means universities, industry, special interest groups, private citizens, elected officials, or any other entity with an interest in the outcome except for DOE and DOE contractors. Tribal Governments and Regulators are acknowledged separately.
} 
Table 1. MWFA product requirements (success criteria).

\begin{tabular}{|c|c|}
\hline Requirement & Definition \\
\hline correct & $\begin{array}{l}\text { The MWFA shall deliver technologies that are technically correct. Such } \\
\text { technologies shall be able to (1) treat target waste streams identified in } \\
\text { FFCA Site Treatment Plans, and ( } 2 \text { ) treat wastes to meet Environmental } \\
\text { Protection Agency (EPA) treatment standards (and Toxic Substance } \\
\text { Control Act or state-regulated treatment standards, where applicable) } \\
\text { and comply with disposal facility waste acceptance criteria. }\end{array}$ \\
\hline complete & $\begin{array}{l}\text { The MWFA shall deliver treatment technologies for mixed low-level and } \\
\text { mixed transuranic waste that make needed treatment systems technically } \\
\text { complete. }\end{array}$ \\
\hline $\begin{array}{l}\text { acceptable to } \\
\text { stakeholders }\end{array}$ & $\begin{array}{l}\text { The MWFA shall deliver mixed waste treatment technologies that are } \\
\text { acceptable to the stakeholders, tribal governments, and regulators. }\end{array}$ \\
\hline $\begin{array}{l}\text { acceptable to } \\
\text { an end-user }\end{array}$ & $\begin{array}{l}\text { The MWFA shall deliver mixed waste treatment technologies to users } \\
\text { committed to pursuing the use of those technologies. }\end{array}$ \\
\hline permittable & $\begin{array}{l}\text { The MWFA shall deliver mixed waste treatment technologies along with } \\
\text { sufficient data to show that there are no probable technical reasons to } \\
\text { prevent receiving a permit to implement the technology in an operational } \\
\text { facility as part of a treatment system. The permit process will be } \\
\text { facilitated by involvement with national regulatory organizations such as } \\
\text { National Technical Workgroup (NTW) on Mixed Waste Treatment and } \\
\text { Interstate Technology and Regulatory Cooperation (ITRC) Subgroup - } \\
\text { This will include working with the regulators both to improve } \\
\text { technologies and/or a facility's ability to obtain a permit. }\end{array}$ \\
\hline safe & $\begin{array}{l}\text { The MWFA shall deliver mixed waste treatment technologies that can be } \\
\text { safely operated. }\end{array}$ \\
\hline timely & $\begin{array}{l}\text { The MWFA shall deliver mixed waste treatment technologies in time to } \\
\text { meet treatment schedules in the FFCA Site Treatment Plans. }\end{array}$ \\
\hline cost-effective & $\begin{array}{l}\text { The MWFA shall deliver mixed waste treatment technologies that are } \\
\text { cost-effective, as determined by a supporting life-cycle cost analysis. }\end{array}$ \\
\hline sufficient & $\begin{array}{l}\text { The MWFA shall deliver sufficient mixed waste treatment technologies } \\
\text { to provide acceptable treatment alternatives for mixed waste (excluding } \\
\text { mixed high level waste and spent nuclear fuel) identified in FFCA Site } \\
\text { Treatment Plans. }\end{array}$ \\
\hline
\end{tabular}




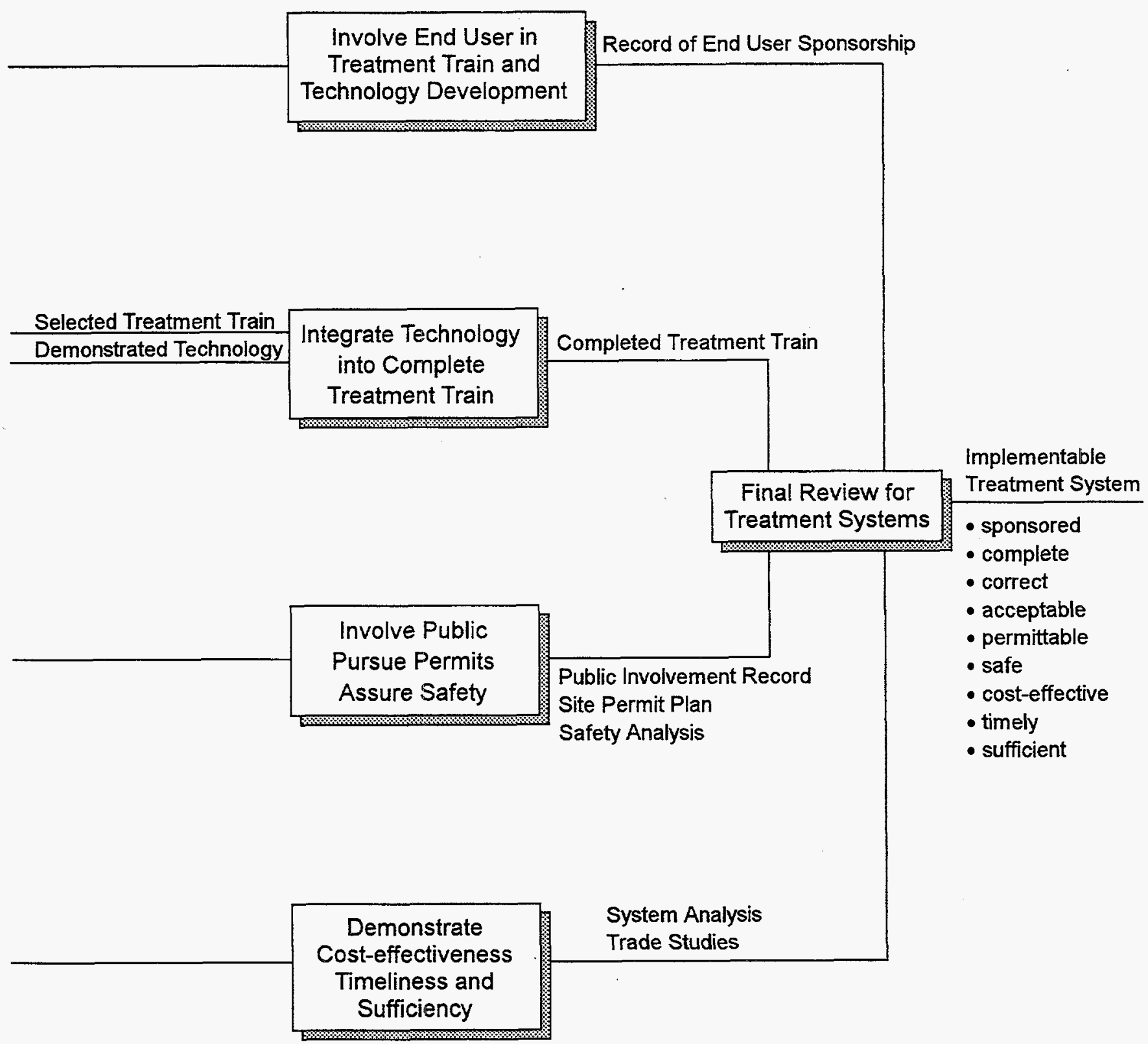

Figure 1. MWFA systems architecture. 


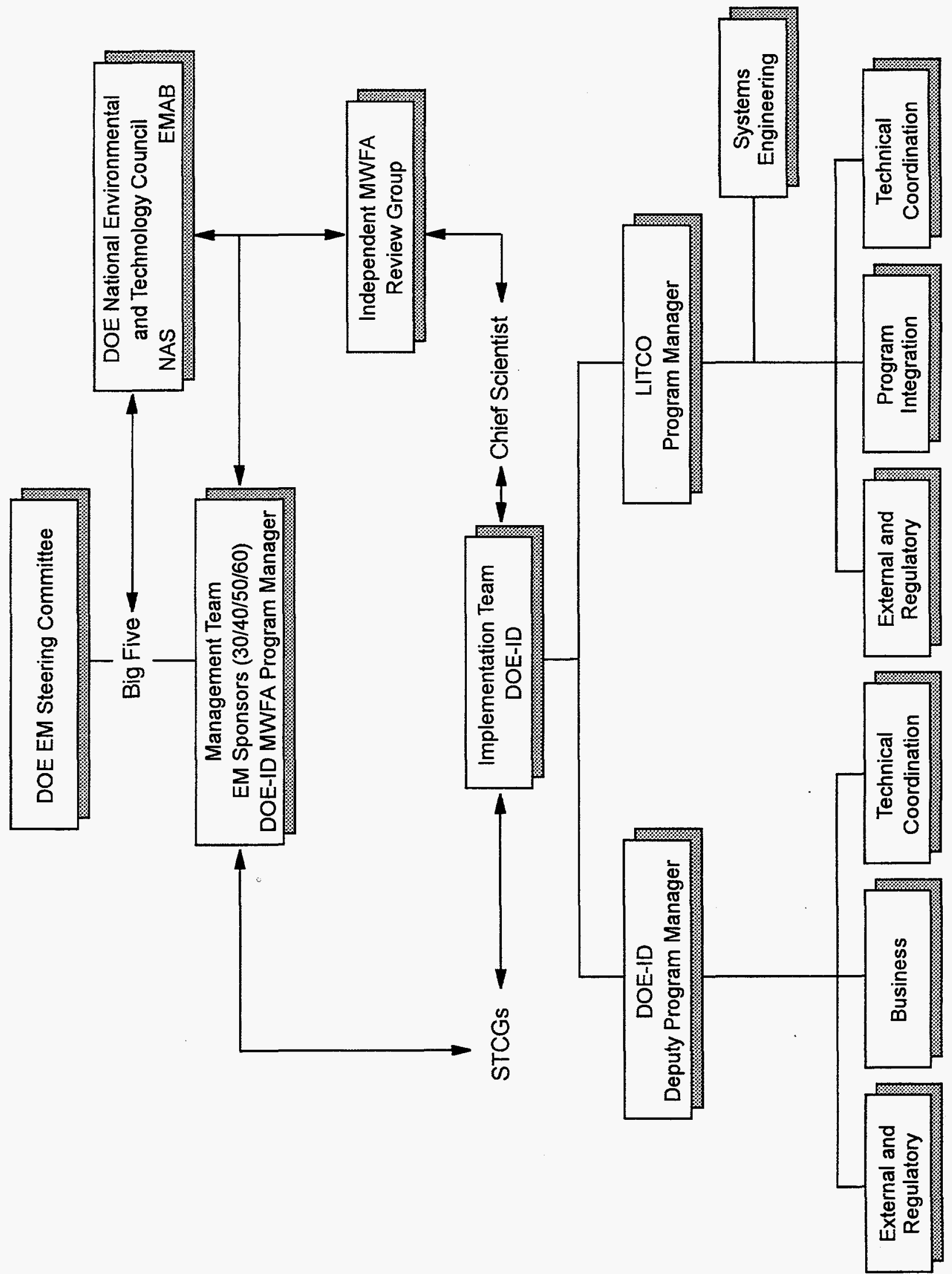

Figure 2. MWFA organization. 


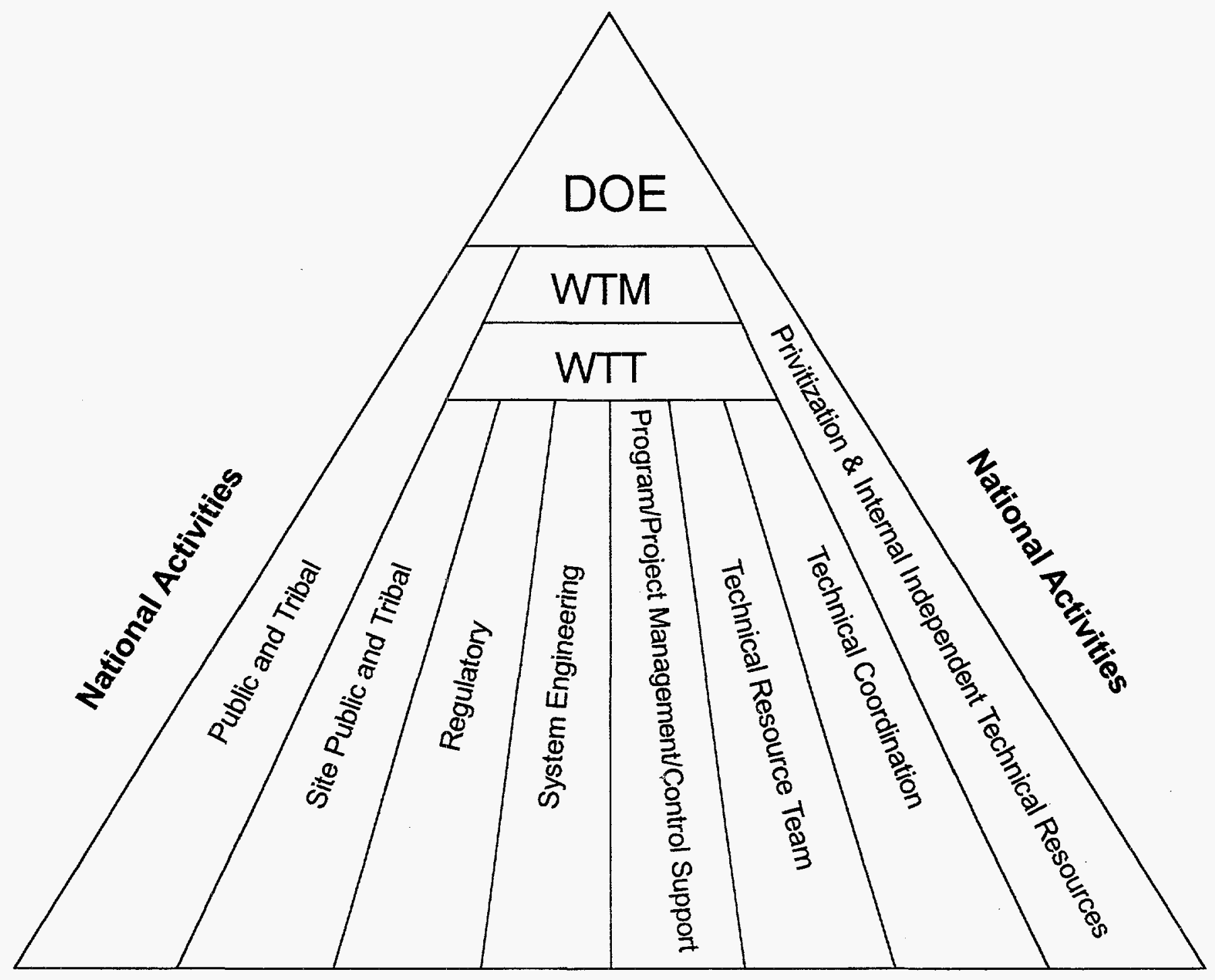

Figure 3. MWFA decision-making paradigm. 


\section{TRIBAL AND PUBLIC INVOLVEMENT}

\subsection{Goals and Objectives}

The tribal and public involvement organization of the MWFA Regulatory and External Liaison Product Area is responsible for facilitating meaningful tribal and public involvement within the MWFA (see Figure 4). The goal is to enhance implementation of mixed waste treatment systems by actively involving tribal governments and stakeholders in the MWFA technology development and decision-making process (see Figure 5). This goal will be reached by accomplishing the following objectives: (1) involve national stakeholder groups and tribal entities in the development of MWFA decision-making criteria and facilitate the development and review of MWFA Risk Data Sheets (RDS) and test plan guidance as prescribed by DOE policy, (2) issue a report identifying stakeholder and tribal points of contact at each site affected by MWFA activities and document mechanisms for involvement through existing protocols and/or agreements, (3) identify tribal and public site-specific issues of concern with respect to the proposed treatment systems and document those issues of concern in a written report,

(4) communicate that information to the MWFA technical coordination team, waste type managers (WTM), waste type teams, and systems engineers such that the information can be translated into criteria and requirements for technology guidance documents and test plans, (5) develop and conduct a workshop(s) to enhance communications between technical and nontechnical people, and (6) disseminate MWFA information to internal and external customers through various communications mechanisms such as the MWFA Home Page, MWFA display, brochures, videotapes, advertisements, published reports, and news articles.

\subsection{Tribal and Public Involvement Steering Committee}

To accomplish the goals and objectives previously identified, the MWFA organized a support group known as the Tribal and Public Involvement Steering Committee (TPISC). Members of the TPISC represent DOE, contractor and subcontractor personnel with training and expertise in the areas of tribal and public involvement, community relations, communications, project management, and business development. The primary objective of the TPISC was to develop a tribal and public involvement strategy which supports a national tribal and public involvement framework set forth by the DOE Office of Science and Technology (OST). The activities of the steering committee are to: (1) conduct research and delineate key lessons learned from previous tribal and public involvement activities with the DOE and other federal and state agencies and extrapolate those lessons learned into general issues of concern (principles), ${ }^{b}$ (2) overlay those issues of concern with the MWFA technology development system and identify opportunities for integration, and (3) develop an implementation plan to integrate tribal and public involvement into the MWFA technology development and decision-making process.

b. This research is documented in the report entitled, "Taking Stock: An Overview of Public Participation Lessons Learned By the U.S. Department of Energy, 1990-1995", issued August 1, 1995. 


\section{Regulatory/External Liaison Programs}

Richard Kimmel - DOE-ID

Susan Prestwich - DOE-ID

Kliss McNeel - LITCO
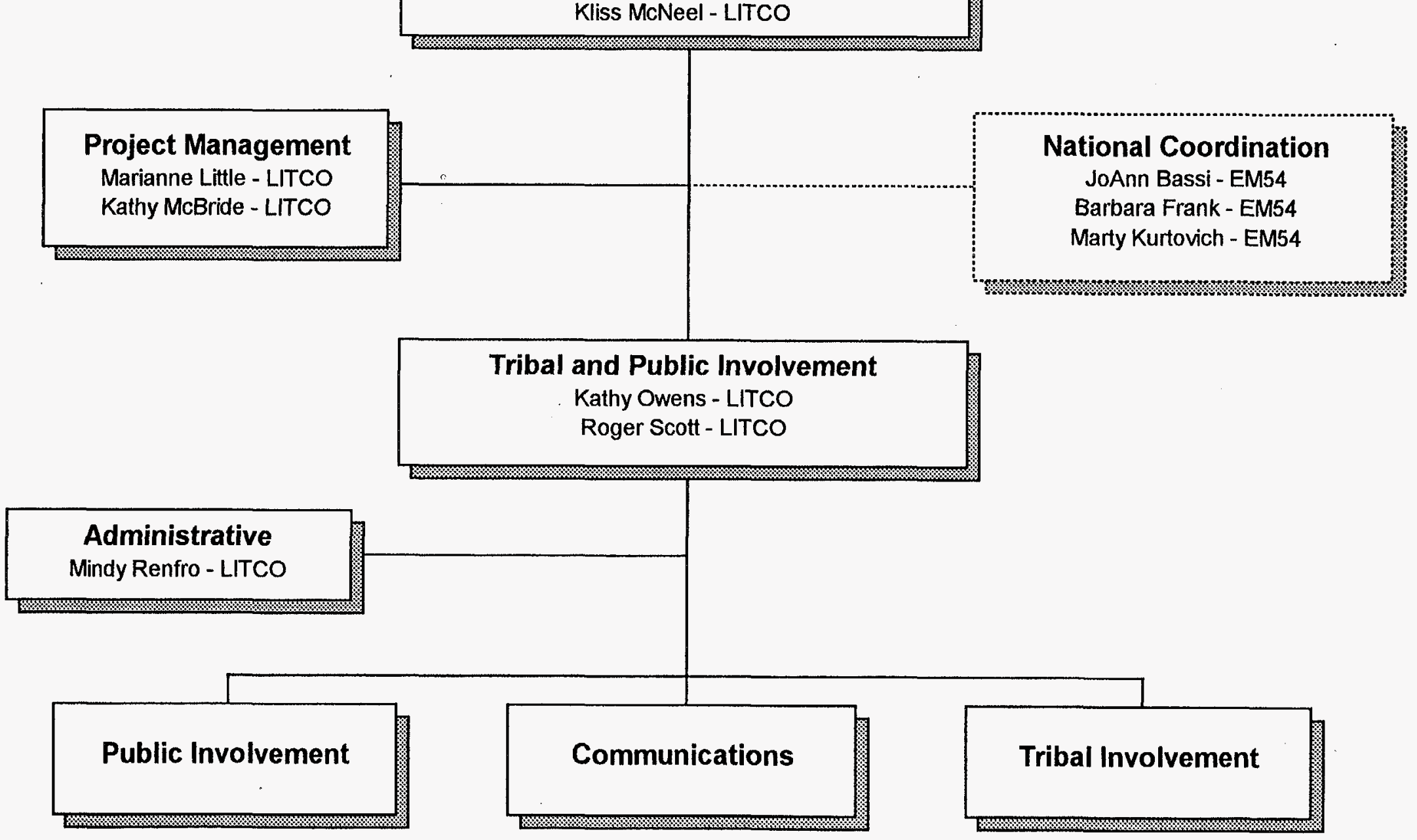

M. Mayo - Colorado Center for Environmental Management T. Smith - State of Idaho

L. Tucker - PR Plus

P. Kent - Coleman Research

G. Swartz - Swartz \& Associates

J. Wilson - J.K. Research Associates 


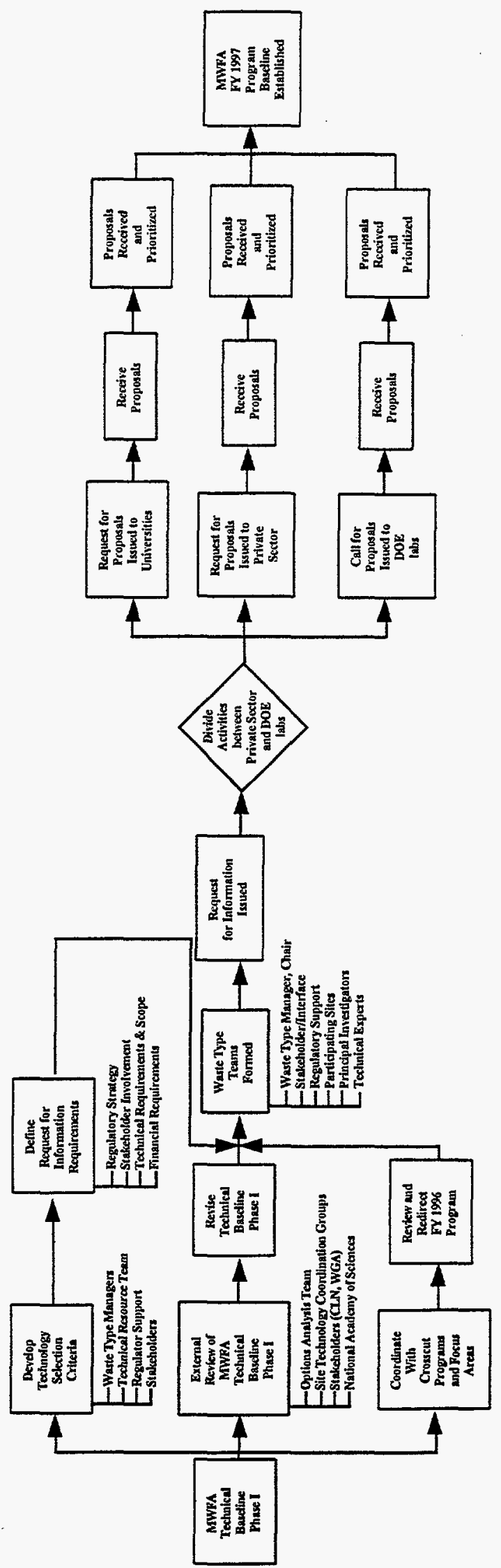

Figure 5. Technical baseline development process. 


\subsection{Communications}

Much of the success of the MWFA depends upon the ability of the Implementation Team to effectively communicate with various audiences, internal and external to DOE (see Table 2). Previous experience dictates that communication strategies need to be tailored for the respective audience. Therefore, the Tribal and Public Involvement Team of the MWFA is responsible for developing and implementing a comprehensive Communication Plan to effectively reach these various audiences. The MWFA uses one or more of the following communication methods, depending upon the intended audience: (1) visual (i.e., displays, graphics, videotapes, and posters), (2) written (i.e., brochures, fact sheets, advertisements, reports, and documents), (3) electronic (i.e., internet, home pages, e-mail, and video/teleconferencing), and (4) participation (i.e., meetings, conferences, workshops, and roundtables).

In the tribal and stakeholder involvement arena, the most effective, and possibly the most contentious, method of communicating is mechanism number four, participation. Historically, exchanges between technical and nontechnical people have not been productive because of the communications gap that exists between them. Therefore, another product of the Tribal and Public work element is to develop a Technical/Public Communication Workshop for technically trained MWFA staff and tribal and public representatives. This workshop will be co-developed with the MWFA Technical Resource Team. 
Table 2. MWFA communications internal and external audiences.

\begin{tabular}{|c|c|}
\hline Internal & External \\
\hline $\begin{array}{l}\text { Sponsor } \\
\text { - Environmental Management Office of Science and } \\
\text { Technology (EM50) - OST }\end{array}$ & $\begin{array}{l}\text { Federal Agencies } \\
\text { - Department of Defense } \\
\text { - Department of Commerce } \\
\text { - Department of Interior } \\
\text { - Department of Transportation }\end{array}$ \\
\hline $\begin{array}{l}\text { Customers } \\
\text { - EM30 - Office of Waste Management } \\
\text { - EM40 - Office of Environmental Restoration } \\
\text { - EM60 - Office of Nuclear Material and Facility Stabilization }\end{array}$ & $\begin{array}{l}\text { Regulatory Agencies } \\
\text { - EPA } \\
\text { - Nuclear Regulatory Commission } \\
\text { - State } \\
\text { - Tribal }\end{array}$ \\
\hline $\begin{array}{l}\text { Other DOE Programs/Projects } \\
\text { - Focus Areas } \\
\text { - CrossCut Programs } \\
\text { - Rapid Commercialization Initiative } \\
\text { - Morgantown Energy Technology Center } \\
\text { - Integrated Non-thermal Treatment Studies (INTS) }\end{array}$ & $\begin{array}{l}\text { Tribal Entities } \\
\text { - Indian Nations } \\
\text { - Tribal Councils } \\
\text { - } \quad \text { Council of Energy Resource Tribes } \\
\text { - National Tribal Environmental Council }\end{array}$ \\
\hline $\begin{array}{l}\text { DOE Facilities } \\
\text { - INEL } \\
\text { - Hanford } \\
\text { - Oak Ridge } \\
\text { - Savannah River } \\
\text { - Fernald } \\
\text { - Los Alamos } \\
\text { - Sandia } \\
\text { - Rocky Flats } \\
\text { - Lawrence Livermore } \\
\text { - } \text { Brookhaven } \\
\text { - } \text { Albuquerque }\end{array}$ & $\begin{array}{l}\text { Special Interest Groups } \\
\text { - Environmental } \\
\text { - } \text { Community } \\
\text { - } \text { Political } \\
\text { - National Governors Association } \\
\text { - } \text { Sestern Governors Association } \\
\text { - NTW } \\
\text { - Professional Societies } \\
\text { - Labor Unions }\end{array}$ \\
\hline $\begin{array}{l}\text { Other Environmental Management (EM) Offices } \\
\text { - EM } 1,2,3,4,5 \\
\text { - } \text { EM10 } \\
\text { - EM20 }\end{array}$ & $\begin{array}{l}\text { Elected Officials } \\
\text { - } \text { Federal } \\
\text { - State } \\
\text { - County } \\
\text { - City }\end{array}$ \\
\hline $\begin{array}{l}\text { Advisory Boards/Groups } \\
\text { - Environmental Management Advisory Board } \\
\text { - Site Specific Advisory Board (SSAB) } \\
\text { - Site Technology Coordination Group (STCG) } \\
\text { - Federal Advisory Committee to Develop Onsite Innovative } \\
\text { Technologies } \\
\text { - State and Tribal Governments Work Group } \\
\text { - Community Leaders Network (CLN) }\end{array}$ & $\begin{array}{l}\text { Industry/Commercial } \\
\text { - } \quad \text { Suppliers } \\
\text { - } \quad \text { Services } \\
\text { - } \text { Manufacturing } \\
\text { - } \text { Marketing } \\
\text { - Investors } \\
\text { - } \quad \text { End-Users }\end{array}$ \\
\hline $\begin{array}{l}\text { MWFA Implementation Team } \\
\text { - LITCO } \\
\text { - Waste Type Managers } \\
\text { - Waste Type Teams }\end{array}$ & $\begin{array}{l}\text { Academia } \\
\text { - Universities } \\
\text { - Technical Schools } \\
\text { - Consortiums }\end{array}$ \\
\hline $\begin{array}{l}\text { MWFA Management Team } \\
\text { - DOE-ID } \\
\text { - DOE Headquarters (DOE-HQ) }\end{array}$ & $\begin{array}{l}\text { International } \\
\text { - Russia }\end{array}$ \\
\hline
\end{tabular}




\section{ACCOMPLISHMENTS}

The accomplishments of the MWFA Tribal and Public Involvement Team during the first quarter of FY-96 are presented in chronological order. Status of ongoing activities are discussed at applicable intervals. Products meeting major milestones are noted accordingly.

\subsection{October 1995}

\subsubsection{MWFA TPISC Meeting}

A 2-day meeting was held in Idaho Falls, Idaho with the TPISC. The objectives of the meeting were: (1) to present the TPISC recommended approach for tribal and stakeholder involvement to the MWFA management and implementation teams, (2) to draft an outline for the MWFA Tribal and Public Involvement Plan, (3) to review and comment on a proposed MWFA communications strategy, (4) to identify windows of opportunity within the MWFA technical baseline schedule to involve tribes and stakeholders, and (5) to work with the MWFA systems engineers to overlay tribal and stakeholder activities onto the technology development systems approach. Other participants of the meeting included members of the DOE-ID management team, and the LITCO Program Integration and Controls and Technical Coordination Teams.

\subsubsection{A Model for Tribal and Stakeholder Involvement in the MWFA System}

As a follow-on product resulting from the lessons learned referenced in Section 2.2 of this report, the TPISC developed a model to depict how tribal and stakeholder involvement follows a parallel path with technology development activities. This model was overlayed with the MWFA technical baseline development process (Figure 5). Key decision points common to both paths or "windows of opportunity" were identified. Each of those windows of opportunity were extrapolated to identify key participants, methodology, and end products. This model is being tested through the MWFA systems architecture and will be enhanced and modified as engineered systems are developed for the site-specific treatment trains (Figure 1).

\subsubsection{Lessons Learned - Permitting R\&D Activities}

The TPISC issued a 2-page white paper that summarized lessons learned for obtaining a research and development $(\mathrm{R} \& D)$ permit. This white paper was a follow-on product to a report drafted in FY-95, Research and Development Permitting Protocol, ${ }^{\mathrm{c}}$ under TTP Number ID752013. This funded the INEL Site Implementation Team of the Federal Advisory Committee to Develop On-Site Innovative Technologies (DOIT). The protocol addresses regulatory requirements related to research and development activities under RCRA and will be used as a guidance document to assist technology developers in preparing permit applications.

c. M. Hinman, RCRA Permitting Protocol for Hazardous and Mixed Waste Research, Development, and Demonstration Activities, Draft, January 1996. 
Five key lessons were described in the white paper: (1) clearly identify R\&D objectives of the research activity to be permitted, (2) submit a complete application, (3) communicate early and often with the regulator, (4) National Environmental Policy Act of 1969 (NEPA) review should be conducted early in the planning cycle, and (5) public involvement should not be left to the regulator alone. The permit applicant should consider its own public and tribal involvement strategy based upon the nature of the activity to be permitted. ${ }^{d}$ As a result of these lessons learned, the MWFA Tribal and Public Involvement Team will assist the MWFA Waste Type Teams in developing that strategy.

\subsubsection{OST Exhibition for the United States Senate}

The DOE EM50 and the International Union of Operating Engineers cosponsored a science and technology exhibition for the U.S. Senate, October 31-November 1, 1995, in Washington, D.C. The exhibition emphasized EM50 accomplishments, technology transfer, enhancements toward technology implementation, and opportunities for economic development. The MWFA display was featured with other EM50 programs.

\subsubsection{MWFA Advertisements}

The MWFA communications staff has learned through previous EM50 programs that generating interest in the commercial sector to enter into partnerships with DOE EM Programs has been limited. This has been attributed to inadequate or improper marketing practices on the part of DOE. Marketing surveys show that one of the most successful and economical communications tools for reaching a broad spectrum of audiences is through advertisements placed in selected technical journals and magazines. MWFA advertisements placed in issues of Remediation Management Magazine, Environment Today, and R\&D Magazine has resulted in fifteen direct inquiries. These inquiries are logged, entered into the MWFA database, and forwarded to the appropriate MWFA point of contact for follow up.

\subsection{November 1995}

\subsubsection{Plasma Hearth Process (PHP) Open House}

On November 8, 1995, Science Applications International Corporation (SAIC), the MWFA, and the INEL DOIT Site Team cosponsored a formal open house at the SAIC Star Center. The purpose of the Open House was to allow the public to see the air pollution control system for the PHP radioactive bench-scale demonstration. The open house provided the public with a unique opportunity to see and comment on the technologies before they were transferred to Argonne National Laboratory-West. Approximately 200 people attended the open house, including families, elected officials, business leaders, Shoshone-Bannock tribal members, Lockheed, Argonne, and DOE employees. The event was covered by two local television stations, radio stations, and several regional newspapers. Although project staff anticipated some opposition or concern regarding the radioactive testing and thermal treatment technique, exit surveys indicated that the open house left a favorable impression with the attendees. The surveys indicated a

d. M. Hinman, "Lessons Learned Permitting Research and Development (R\&D) Activities," March 1996. 
greater interest in the technology's link to enhancing the Idaho work force and the potential economic benefits derived from its development than any perceived environmental or health risk.

\subsubsection{TRU, Mixed TRU, and MLLW Treatment Technologies Technical Peer Review}

A member of the MWFA TPISC participated in the TRU, mixed TRU, and MLLW Treatment Technologies Technical Peer Review Meeting held in Dallas, Texas, November 13-15, 1995. This peer review was sponsored by the Landfill Stabilization Focus Area and the MWFA. The purpose of the review was to achieve an independent evaluation of current and past technology development studies and demonstrations in this area and to recommend technical support and development thrusts for FY-97. Two panels were invited to observe the technical presentations and to provide comments to the two focus areas. The two panels consisted of a DOE user group and a technical group consisting of academia and industry experts. The MWFA TPISC member was elected chairperson for the user panel and was a contributor to the final report. ${ }^{1}$ General comments from the review are noted as follows:

- The DOE OST (EM50) has been funding thermal and nonthermal technology development for the past several years. The best return on investment of limited DOE dollars is reflected in the thermal treatment technologies, so development efforts should be focused there.

- The success of the focus areas will depend upon communications about technology to nationwide stakeholders.

- Due to the problems associated with MLLW (i.e., difficult to handle, have different health and environmental problems, and are controlled by overlapping sets of regulations and requirements), treatment of MLLW will require agreement by the appropriate states through the Site Treatment Plan process.

- Many of the available technologies include some type of incineration or thermal destruction treatment and may face intense public and regulatory scrutiny.

- EM50 should foster and support technology development that is less provincial and more DOE-wide in terms of the problems they address. The technologies that should be supported are multisite, multiwaste-stream in nature, and involve "live" demonstrations (as opposed to using surrogate wastes).

\subsubsection{MWFA Marketing and Communication Implementation Schedule}

A draft report of the MWFA Marketing and Communications Implementation Schedule was issued in November, meeting a DOE-HQ milestone. ${ }^{e}$ This report outlines the MWFA approach to communicating with our internal and external customers, tribes, regulators, and stakeholders from a marketing perspective. This implementation schedule defines the activities, products, and

e. L. Tucker and J. Wilson, "Mixed Waste Focus Area Marketing and Communication Implementation Schedule," Draft, January 1996. 
person responsible for enhancing communications to help the MWFA meet its mission. The primary objectives of this schedule are:

- Assist the DOE waste type teams and waste type managers in communicating with the management and implementation teams, DOE customers and end-users, stakeholders, tribes, and regulators to improve the technology screening, research, development, and demonstration process.

- Publicize "quick wins" to enhance the MWFA's visibility and success.

- Assist the MWFA DOE Management Team in keeping lines of communications open between DOE-HQ, DOE Operations Offices, regulators, tribes, and stakeholders.

- Help bridge the communication gap between the MWFA, tribes, and public sectors by reporting progress to keep our audience informed of which technologies are advancing toward implementation.

- Help the MWFA transfer parts or entire projects to the commercial sector and facilitate the commercialization or spin-off of a technology by alerting private industry to partnership opportunities.

- Communicate MWFA needs to industry, universities, and other DOE laboratories to enhance opportunities for sharing information, personnel, resources, and funds.

- Help promote partnership opportunities with universities, the private sector, and other federal and state agencies to accelerate and enhance demonstration capabilities.

The activities identified in this implementation schedule are being integrated into the appropriate functional elements of the MWFA implementation team and will be reflected in associated work packages.

\subsubsection{U.S. DOE MWFA Tribal and Public Involvement Plan}

The first working draft of the U.S. DOE Mixed Waste Focus Area Tribal and Public Involvement Plan was completed in November. ${ }^{f}$ This plan describes how the MWFA will communicate with and involve tribal governments and stakeholders in its technology development and decision-making processes and how the MWFA Tribal and Public Involvement Team will provide resources and support to the DOE waste type managers and waste type teams.

This plan focuses on working with existing organizations and resources such as the SSAB and STCG. The plan is structured around four primary goals and defines supporting objectives and activities. Those four primary goals are the following:

f. G. Swartz, U.S. Department of Energy Mixed Waste Focus Area Tribal and Public Involvement Plan, Predecisional Draft, Working Draft Version 0.3, January 1996. 
- Create a partnership between the MWFA waste type managers, waste type teams, tribes, local governments, and other stakeholders for the purpose of developing a DOE MWFA technology assessment and selection program that integrates tribal and public involvement principles through existing tribal and public participation resources.

- Integrate selected components of the MWFA Marketing and Communication Schedule.

- Provide collaborative decision-making and group communications skills training for participants in the DOE MWFA technology development, assessment, and selection process.

- Facilitate early and ongoing partnerships with regulatory entities through design and implementation of a proactive program (beyond current programs such as NEPA, RCRA, etc.) to provide opportunities for early and ongoing dialogue with regulators responsible for permitting the construction and operations of mixed waste treatment facilities.

This plan is intended to be responsive to the needs of tribes, local governments, and publics. It provides a framework for technical personnel to interact with tribal and stakeholder entities for the purpose of enhancing the technology development process and implementation of the final products of that process.

The activities described in this plan are being integrated within the various functional elements of the MWFA and implemented through the MWFA Tribal and Public Involvement Work Package.

\subsubsection{Environmental Management Forum}

The MWFA Public Involvement and Communications staff participated in the 3rd Annual Environmental Management Forum held in Orlando, Florida, November 15-17, 1996. The MWFA display was included as part of the Exhibitors Program and an overview of the MWFA was presented in a session entitled, "Technology Innovators." The Environmental Management Forum is sponsored by Environment Today magazine and the National Association for Environmental Management. The forum is attended by industrial environmental managers from across the country and represent various business disciplines such as health care, utilities (gas and electric), chemical, oil and gas refineries, paper and wood products, mining, electronics, food and beverage, engineering, and analytical laboratories. The purpose of MWFA participation was to expand visibility of the MWFA to the private sector and to discuss commercialization, technology transfer, and partnership opportunities. The MWFA received a dozen serious inquiries from attendees and was approached by Technology Transfer Business magazine for possible story lines for feature articles.

\subsubsection{Envirocare Facility Tour}

The Envirocare Mixed Waste Treatment Facility in Tooele, Utah, entered into a cooperative agreement with the DOE to implement the macroencapsulation technology developed through the MWFA. The technology is a polymer encapsulation process that will be used to treat 
radioactive contaminated lead for permanent disposal. The lead will be shipped to the facility from various DOE sites around the country. The MWFA provided communications staff support for the DOE-sponsored tour. A videographer and reporter covered the event. The event was covered by local television and newspapers, as well as the Associated Press. Response to the national coverage has been extremely favorable and inquiries about the technology have been received from as far away as Switzerland through the Swiss Embassy.

\subsection{December 1995}

\subsubsection{MWFA Crosswalk Between Stakeholder Principles and Technical Criteria}

DOE has entered into a new era of openness to reflect the change in DOE's mission from national defense programs to energy and environmental restoration/management programs. As a result, the Assistant Deputy Secretary of the DOE OST has encouraged technology development program managers to embrace this "new openness approach" in all facets of decision-making. However, one of the greatest challenges that has evolved from this new approach is how to narrow the gap between the "Alpha and the Omega".g More often than not, political, societal, and cultural values are driving technical and scientific decisions, leaving technology developers with the difficult task of adequately incorporating "omega" principles into their scientific methods. As a point in fact, one of the MWFA technology performance requirements is that the technology be "acceptable to the public." However, from a technical perspective that requirement is too ambiguous to be included as a design specification for a technology. Therefore, the MWFA TPISC hypothesized that if an intangible, value-based principle can be linked to a technical criteria and then extrapolated into performance metrics (e.g., regulatory permitting standards), then the technology developer can easily incorporate that performance requirement into the engineered design of the technology.

To test the hypothesis, the MWFA Tribal and Public Involvement Team used as a model the crosswalk completed by the Technical Support Group and the Tribal and Stakeholder Working Group of the INTS Project. A crosswalk was performed between the stakeholder principles developed by the INTS and the technical criteria developed by the MWFA Technical Resource Team for ranking, selecting, and evaluating technology proposals for the mixed waste treatment train technology deficiencies. ${ }^{\text {h }}$ In most cases, a stakeholder or regulatory principle could be linked directly to a technical criteria. ${ }^{i}$ The results of this crosswalk suggest that if "omega" principles can be directly linked with technical criteria, then there is a high probability of extrapolating those intangible principles into tangible performance metrics.

g. "Alpha" and "Omega" are used in this context as euphemisms for science-based and nonscience-based principles, respectively.

h. M. Hinman, Mixed Waste Focus Area Crosswalk Between Stakeholder Principles and Technical Criteria, December 1995.

i. Because the stakeholder principles and criteria for the INTS were developed specifically for nonthermal treatment systems, some gaps were expected when applied to the MWFA technical criteria that included thermal treatment systems. 
The MWFA Tribal and Public Involvement Team is using this crosswalk approach to identify applicable performance specifications for the treatment train deficiencies. The team will solicit input from the sites to verify stakeholder, tribal, and regulatory/permitting criteria relative to the specific technical application of the proposed deficiency. Then the MWFA Waste Type Teams can complete a crosswalk with the technical criteria and extrapolate that criteria to the applicable performance standards. Those technical performance standards can be used toward establishing a baseline for technology test objectives and for field operating requirements.

\subsubsection{MWFA Public Involvement and Communications Organization and External Interfaces}

TPISC issued a white paper that describes the Tribal and Public Involvement Team of the MWFA and discusses the various regional and national work groups and other DOE initiatives that either directly or indirectly influence the activities of the MWFA. ${ }^{2}$ This paper was intended to provide the MWFA Management and Implementation Teams with a brief summary of the various tasks and products of this work element, introduce the LITCO team members, and identify subcontracted and leveraged personnel who are key contributors to products and deliverables.

\subsubsection{PHP Funding Review}

On December 12, 1995, a facilitated meeting was held in Salt Lake City, Utah, between representatives of the MWFA Management and Implementation Teams, representatives of the PHP Project, and members of the INEL Site Implementation Team and Mixed Waste Working Group of the Federal Advisory Committee to DOIT. The purpose of the meeting was to discuss MWFA program objectives, the technical path forward for the PHP, and the proposed field scale demonstration scope reduction. The impetus behind this meeting was a recommendation from the Assistant Deputy Secretary of the DOE OST to involve the DOIT stakeholder groups in any decisions impacting the DOIT Technology Test Cases.

The meeting participants were presented an overview of the PHP Project and proposed alternatives for the technical path forward to compensate for impending funding reductions. After much discussion, the participants decided to forego the proposed alternatives and to keep the field-scale demo viable as a "technical insurance policy" until such time as another plasma treatment technology being developed at the INEL is proven successful.

Although this decision was not the preferred alternative of the MWFA Technical Resource Team, it was a decision that the majority could "live with." One could argue that some of the claimed attributes of the PHP have never been scientifically quantified and should not have been allowed as discussion points or used as a basis for the decision, and to debate the issues at this meeting was inappropriate and should have been resolved at a previous opportunity. Since there was a general sense among the MWFA technical staff that the stakeholder group did not have any pre-conceived notion of how this project should proceed prior to the meeting the MWFA Implementation Team conducted a situation analysis. It was determined that the outcome was due to lack of preparation on the part of the MWFA by introducing an element of doubt in the stakeholder's minds about the proposed alternatives. In addition, another mitigating factor 
contributing to the outcome was that clear ground rules were not established, nor were the roles of the participants and observers defined at the beginning of the meeting. Process improvements and corrective actions are addressed in Section 3.3.4.2.

\subsubsection{MWFA/CLN Meeting}

On December 13-14, 1995, a meeting was held in Salt Lake City, Utah, between the MWFA Management and Implementation Teams and members of the CLN Mixed Waste Sub-Group. The purpose of the meeting was to develop and weight evaluation criteria for selecting and ranking proposals to fill technology deficiencies in the mixed waste treatment systems proposed in the FFCA Site Treatment Plans. In addition, the CLN assisted the MWFA in drafting the request for interest for the technology proposals.

Theoretically, the meeting was viewed a success because the primary objectives were accomplished and the stakeholder participants expressed an appreciation for the opportunity to participate in a meaningful decision-making activity. Suffice it to say, however, that the activity did not go without some problems. A comprehensive situation analysis was performed by an independent party who did not participate in the meeting. ${ }^{j}$ Primary issues and respective process improvements and corrective actions are summarized below:

\subsubsection{Issues.}

- Communications - Meeting participants (technical and nontechnical) did not understand the purpose or objectives of the meeting, could not differentiate between the different roles, and could not effectively communicate with each other.

- Expectations - DOE and its contractors had not come to an agreement on the purpose of the CLN participation and tended to use the meeting as a platform to "hammer out" their differences on the issue. The CLN mixed waste subgroup had not yet met as a group unto themselves and therefore had no mutual agenda or expectation as a cohesive entity.

- $\quad$ Roles - A perceived "hierarchy" guided the direction of the meeting. Stakeholders were welcomed but were not viewed as being part of the decision-making group. DOE and contractor public involvement support staff were viewed as "pseudo stakeholders" and dominated the discussions to drive the criteria to meet personal agendas. MWFA Public Involvement Steering Committee staffers were also viewed as acting like "pseudo stakeholders" rather than remaining in their support roles.

- Preparation/Education - No advance training or preparation was provided to the technical people in terms of how to communicate with nontechnical people or how to consider nonquantifiable data or criteria. There was no advance education or

j. G. Swartz, "Summary of Communications Issues," DOE Mixed Waste Focus Area and Community Leaders Network Meeting, Salt Lake City, Utah, December 13-15, 1995. 
preparation for the CLN members to establish a foundation of understanding of the MWFA mission, goals, and objectives, which limited their ability to communicate.

- Meeting Facilitation - Some participants saw the facilitator as being technically ineffective and not sensitive to the stakeholders, while others felt the facilitator was intentionally over-ridden by MWFA technical people and lost control.

- Predetermined Agendas/Outcome - Technical staff were perceived as coming to the meeting with a pre-determined outcome. DOE and contractor public involvement staff were viewed as pushing their own agendas which served to exclude the "real" stakeholders. MWFA technical staff were viewed as being so attached to their approach they couldn't (or wouldn't) understand the nontechnical side of the discussion.

- Meeting Product/Results - Some participants felt that the product should have been "better" after two hard days of work, however, others felt that the meeting had mixed results but something positive had been accomplished.

\subsubsection{Process Improvements.}

- Communications - Open, effective, and adequate communication should be regarded as a primary function of all tribal and stakeholder activities.

Corrective Actions:

1. Provide at least 30 days advance notice for meetings.

2. Clearly define proposed goals, products, and outcomes of meetings at least 30 days in advance.

3. Review those goals, etc., with meeting participants at the beginning of the meeting and revise as appropriate.

- Preparation/Education - Tribal and stakeholder involvement must be prefaced by advance preparation, communication, and education.

Corrective Actions:

1. Develop a technical/public communications training program for DOE/contractor managers, technically-trained personnel, and relevant stakeholders/tribal members.

2. Preparation for $\mathrm{DOE} /$ contractor - stakeholder collaboration activities must begin a minimum of one month in advance of the event and should be coordinated through a committee consisting of DOE, contractor, and stakeholder representatives. 
- Expectations - DOE and contractor management expectation must be that a collaborative decision-making partnership with tribes and stakeholders will be positive, productive, and good for business. Tribal and stakeholder involvement must be incorporated as a requirement into management and systems development activities.

Corrective Actions:

1. Develop a broad-reaching "briefing" process for management personnel that: (1) outlines expectations and "incentives" for endorsing tribal and public involvement, (2) defines the roles of management, public involvement personnel, contractor support personnel, and technical staff when participating in public involvement activities, and (3) describes successful methods for conducting public meetings.

- Roles - Clearly define the decision-making process. If such a process has not been identified, provide an opportunity for all participants to assist in writing the definition and defining participants' roles in that process. Ensure that staff personnel and contractors do not take on the role of public participants.

Corrective Actions:

1. Assist managers and technical staff in working with stakeholders as equal participants in the decision-making process.

2. Brief DOE and contractor personnel as to appropriate protocol for bringing tribal and stakeholder issues to the table.

- $\quad$ Predetermined Agendas/Outcomes - If the decision has already been made, if the final product has already been completed, if the outcome has already been determined, then do not waste the time of tribal and stakeholder participants. Do not look at public participation as a "check off box" or "jump through the hoop" exercise.

Corrective Actions:

1. Provide training in collaborative decision-making for all participants, technical and nontechnical, as needed.

- Meeting Facilitation - A facilitator should only be used if the majority of the participants agree such services are required for the efficient progress of the meeting.

Corrective Actions:

1. If participants agree, solicit facilitation service 45 days in advance of meeting.

2. Use a facilitator that is familiar with the subject matter of the meeting. 
3. Be sure the facilitator understands his role. Does the group want an aggressive facilitator or a more passive "discussion mover."

4. Recognize the difference between a facilitator and a mediator. Use a facilitator to run a meeting. Use a mediator to resolve a conflict. If there is no conflict, do not encourage it.

- Meeting Products and Results - Every meeting must have a defined product. A meeting product is not the same as a predetermined outcome.

Corrective Actions:

1. Clearly define the intended product of a meeting and communicate that product to all meeting participants as soon as possible.

2. Develop an agenda and design the meeting format around the product.

3. Design a process that clearly reflects the stakeholder role and their influence on the outcome.

4. Document the outcome and conduct an evaluation of the process.

Many of these corrective actions will be accomplished through implementation of the MWFA Tribal and Public Involvement Plan discussed previously in this document. 


\section{CONCLUSIONS}

The MWFA Tribal and Public Involvement Team successfully accomplished all deliverables and milestones in accordance with the MWFA Regulatory and External Programs Technical Task Plan \#ID06MW83 as of the end of December 31, 1995. These products directly support the mission of the MWFA and the goals and objectives of the MWFA External and Regulatory Liaison Product Area by:

1. Identifying potential windows of opportunity for tribal, regulatory, and stakeholder involvement in the MWFA decision-making processes.

2. Building on the progress of existing tribal and stakeholder groups with whom DOE has established partnerships.

3. Determining the levels of involvement desired by those groups.

4. Developing action plans to facilitate that involvement.

5. Providing resources and funding to support the activities in the plans.

6. Identifying linkages to the MWFA technical and programmatic functional elements.

7. Integrating those activities into the MWFA technical and programmatic baselines through the MWFA waste type teams, systems engineers, and program implementation staff.

8. Providing input for technology evaluation, prioritization, and selection criteria.

9. Recognizing site-specific political, societal, and cultural issues relative to proposed mixed waste treatment systems and extrapolating those issues to applicable technical development criteria and performance specifications.

10. Facilitating communications between the MWFA and its internal and external customers through networking, teaming, training, etc.

11. Encouraging industry and university partnerships through various communication mechanisms.

Major activities scheduled for completion during the second quarter of FY-96 include the following:

- Validation of the success criteria for the Technology Investment Decision Model.

- Identification of a point of contact for stakeholder and tribal organizations at DOE sites (i.e., SSAB and STCG).

- Development of a technical/public communications workshop. 
- Establishment of partnerships with national stakeholder organizations to participate in MWFA program reviews.

- Integration of site-specific tribal and stakeholder issues into technology development planning.

- Development of a reference document and approach for involving tribal governments.

- Implementation of the "final version" of the MWFA Tribal and Public Involvement Plan.

- Coordination of MWFA tribal and public involvement with waste type teams and waste type managers.

- Integration of components of the MWFA Marketing and Communications Schedule into MWFA technical and programmatic activities.

These activities and other ongoing work discussed in this document will be statused through March 31, 1996, and issued as an addendum to this report. 


\section{REFERENCES}

1. H. Bohlinger, N. Brown, C. Cooley, et al., "TRU, TRU Mixed, and Mixed Low-Level Waste Treatment Technologies Technical Peer Review User Panel Report," December 1995.

2. K. Owens, Mixed Waste Focus Area Public Involvement and Communications Organization and External Interfaces, December 1995. 


\section{BIBLIOGRAPHY}

Bernard, E. A., "Technical Criteria for the Integrated Nonthermal Treatment System Study," Technical Support Group, Salt Lake City, Utah, November 1-2, 1995.

Conner, J. E., M. T. Magleby, and R. E. Williams, The Startup and Status of the DOE Mixed Waste Focus Area, February 1, 1996.

DOIT Mixed Waste Working Group, "DOIT Mixed Waste Working Group Model Solicitation Subgroup Draft Stakeholder Involvement Objectives and Process."

DOIT Mixed Waste Working Group, "Guidance Selection Criteria."

DOIT Mixed Waste Working Group, "Process Guidance for Procurement and Implementation of Technology Demonstrations."

DOIT Mixed Waste Working Group, "Request for Expression of Interest - Host Site for Mixed Low-Level Waste Non-thermal Treatment Technology Demonstration," October 1995.

Hinman, M., "RCRA Permitting Protocol for Hazardous and Mixed Waste Research, Development and Demonstration Activities," March 1996.

Letter from D. Gombert, Lockheed Idaho Technologies Company, to Distribution, "Draft Technical Task Plan Proposal Evaluation Criteria," December 22, 1995.

Letter from H. R. O'Leary, Department of Energy, to All DOE Employees, "Guidance on Implementation of the Department's Public Participation Policy," July 29, 1994.

Lockheed Idaho Technologies Company, Draft Mixed Waste Focus Area Program Management Plan, February 1996.

Lockheed Idaho Technologies Company, Mixed Waste Focus Area Waste Type Team Manual, INEL-95/0522, September 29, 1995.

Memorandum from G. A. Beitel to Distribution, Lockheed Idaho Technologies Company, "Draft System Requirements Document-Request for Review," December 21, 1995.

Roach, J. A., Mixed Waste Focus Area, Department of Energy Complex Needs Report, INEL-95/055, November 16, 1995.

Swartz, G., "U.S. Department of Energy Office of Technology Development Integrated NonThermal Treatment Systems Study," Tribal and Stakeholder Working Group Meeting, Denver, Colorado, August 8-9, 1995. 